\title{
An Unusual Presentation of Cytomegalovirus Infection: Generalized Edema
}

\author{
Ceyda Tuna Kirsaclioglu ${ }^{a} \quad$ Gulin Hizal $^{a} \quad$ Esra Karakus $^{b} \quad$ Tulin Revide Saylic $^{c}$ \\ a Department of Pediatric Gastroenterology, Hepatology and Nutrition, Turkish Republic Health Ministry, Ankara \\ Child Health Diseases, Haematology Oncology Training and Research Hospital, Ankara, Turkey; ${ }^{b}$ Department of \\ Pathology, Turkish Republic Health Ministry, Ankara Child Health Diseases, Haematology Oncology Training and \\ Research Hospital, Ankara, Turkey; ${ }^{C}$ Department of Pediatrics, Turkish Republic Health Ministry, Ankara Child Health \\ Diseases, Haematology Oncology Training and Research Hospital, Ankara, Turkey
}

\section{Keywords}

Children · Cytomegalovirus · Edema · Gastritis .

Immunocompetent host

\section{Abstract}

Objective: Cytomegalovirus (CMV) infection may rarely lead to protein-losing gastropathy that presents with nausea, vomiting, abdominal pain, and edema in immunocompetent children, but extremely rarely with only generalized edema. Clinical Presentation and Intervention: A previously healthy 5-year-old boy presented with generalized edema without any other symptoms. He had hypoalbuminemia but no proteinuria. He was evaluated for gastrointestinal protein loss, and hypertrophic gastropathy was revealed on esophagogastroduodenoscopy. Meanwhile, CMV infection was detected by serologic tests and polymerase chain reaction in the blood. He recovered spontaneously within a week. Conclusion: CMV-related protein-losing gastropathy may present with generalized edema without any gastrointestinal symptoms.

(c) 2019 The Author(s) Published by S. Karger AG, Basel

\section{KARGER}

E-Mail karger@karger.com www.karger.com/mpp

\section{(c) 2019 The Author(s) Karge} Published by S. Karger AG, Basel Open access

This is an Open Access article licensed under the Creative Commons Attribution-NonCommercial-4.0 International License (CC BY-NC) (http://www.karger.com/Services/OpenAccessLicense), applicable to the online version of the article only. Usage and distribution for commercial purposes requires written permission.

\section{Introduction}

Cytomegalovirus (CMV) leads to a self-limited and spontaneously recovering infection in healthy individuals [1]. However, CMV-related gastritis and/or proteinlosing gastropathy (PLG) may be seen in immunocompetent children with edema and upper gastrointestinal symptoms, such as vomiting, nausea, and abdominal pain [2-9]. Here, we present a 5-year-old boy with generalized edema due to CMV-related PLG.

\section{Case Report}

A 5-year-old boy was admitted to our hospital with sudden onset of swelling of feet, legs, abdomen, scrotum, and periorbital tissue. At admission, he had no fever, nausea, vomiting, diarrhea, or history of any medication usage. The medical and family histories were insignificant. He was well developed (body weight $19 \mathrm{~kg}$ [50-75th percentile], height $109 \mathrm{~cm}$ [50-75th percentile]), and pretibial, periorbital, and scrotal edema as well as ascites were present. The laboratory tests were as follows (with their normal range in parentheses): hemoglobin and platelet count were normal, the white blood cell count was $13,000 / \mathrm{mm}^{3}(4,500-10,500 /$ $\mathrm{mm}^{3}$ ), and blood smear revealed $64 \%$ lymphocytes, $32 \%$ neutrophils, $2 \%$ eosinophils, and $2 \%$ monocytes. Renal function tests,

Ceyda Tuna Kirsaclioglu

Turkish Republic Health Ministry, Ankara Child Health Diseases

Haematology Oncology Training and Research Hospital

Sehit Omer Halisdemir Cad, TR-06110 Ankara (Turkey)

E-Mail ceytun@yahoo.com 
Fig. 1. Hyperemic, edematous, and thickened gastric folds of the gastric body (a), an aphthous ulceration in the fundus (b), and prominent foveolar epithelial hyperplasia of hypertrophic gastric mucosa $(\mathrm{HE}, \times 400)$ (c).
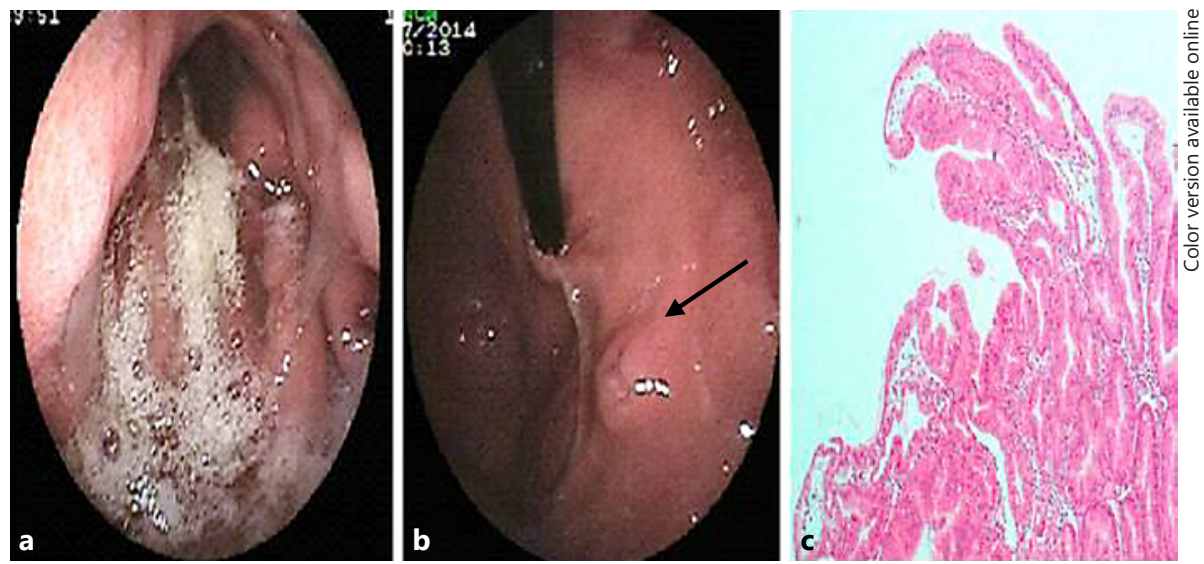

serum electrolytes, transaminases, blood glucose level, C-reactive protein, and erythrocyte sedimentation rate were within normal ranges. Hypoproteinemia (total protein $3.1 \mathrm{~g} / \mathrm{dL}[4.5-6 \mathrm{~g} / \mathrm{dL}]$ ), hypoalbuminemia (albumin $1.8 \mathrm{~g} / \mathrm{dL}$ [3.5-4.5 g/dL]), and hypertriglyceridemia (triglyceride $321 \mathrm{mg} / \mathrm{dL}[<150 \mathrm{mg} / \mathrm{dL}]$ ) were present. Urine examination and spot urine protein/creatinine ratio were normal. Abdominal ultrasonography revealed ascites and bilateral pleural effusion. Because of the absence of proteinuria, a gastrointestinal protein loss was considered. Human albumin ( $1 \mathrm{~g} / \mathrm{kg}$ intravenously, for 2 consecutive days) was given. The relevant tests were performed for infectious, autoimmune, metabolic, immunologic, and cardiologic diseases for the etiologic evaluation. The stool sample was negative for parasites, leucocytes, and erythrocytes. The stool culture was negative for Salmonella and Shigella. The sweat test and total immunoglobulin (Ig) E level were within normal ranges. The other Ig levels were low for his age (IgA $45 \mathrm{mg} / \mathrm{dL}$ [57-282 mg/dL], IgG $118 \mathrm{mg} / \mathrm{dL}$ [701-1,084 $\mathrm{mg} / \mathrm{dL}$ ], and IgM $20 \mathrm{mg} / \mathrm{dL}$ [69-387 mg/dL]). Anti-nuclear antibody and anti-dsDNA were negative. Echocardiography was normal. The upper gastrointestinal endoscopy (UGE) revealed bile reflux, edematous and hyperemic thickened gastric folds (Fig. 1a), and an aphthous ulceration in the fundus (Fig. 1b), while the duodenum was normal. Hypertrophic gastropathy with foveolar epithelial hyperplasia on gastric mucosa (Helicobacter pylori $[-]$ ) (Fig. 1c) and a normal duodenal mucosa were seen in the histopathologic examination. Lansoprazole $(1 \mathrm{mg} / \mathrm{kg} /$ day $)$ and sucralfate were given. Meanwhile, ongoing tests revealed CMV IgM positivity and 2,013 copies/mL of CMV-DNA by polymerase chain reaction (PCR) in the blood. He was discharged when the generalized edema had regressed on the 7th day with a serum albumin level of $2.6 \mathrm{~g} / \mathrm{dL}$. Serum albumin level increased to $3.5 \mathrm{~g} /$ $\mathrm{dL}$ and CMV-DNA decreased to 701 copies/mL on the 21 st day, serum albumin $(4.6 \mathrm{~g} / \mathrm{dL})$ and IgA levels were normalized and CMV-DNA was undetectable in the 2 nd month. In the 3 rd month, serum IgM, IgG, and triglyceride levels were normalized, and a repeated UGE was macroscopically normal. Histopathologic examination revealed $H$. pylori (-) superficial gastritis. During 1-year follow-up, he had no complaints and the albumin levels remained within normal ranges.

Cytomegalovirus Infection Presenting with Generalized Edema

\section{Discussion}

We present here the case of a previously healthy 5 -yearold boy with generalized edema, with neither gastrointestinal symptoms nor proteinuria. Initially, UGE was performed to determine the localization of gastrointestinal protein loss. The presence of hypertrophic gastric folds on UGE, histopathologic findings, CMV IgM antibody, and CMV-DNA (by PCR) positivity in blood helped the diagnosis. With only supportive treatment, the clinical, laboratory, and endoscopic findings improved completely, and no recurrence was seen in a 1-year follow-up period.

Nonspecific symptoms, such as anorexia, nausea, vomiting, fever, diarrhea, abdominal pain, or edema, have been reported to be the presenting symptoms in immunocompetent children with CMV-related PLG [2-9]. Despite the generalized edema being the most evident finding in several reports, it generally occurs following the nonspecific symptoms $[3,4,6,9]$. In addition, erosive gastritis and gastric ulcers have been reported in patients with CMV-related PLG in the absence of $H$. pylori infection as in our patient $[4,7]$.

The mechanism by which CMV affects gastric mucosa is not fully understood. CMV leads to a transient increase in levels of transforming growth factor- $\alpha$, which binds and activates the epidermal growth factor receptor, thus resulting in the enhancement of proliferation of gastric mucosal cells, mucus secretion, foveolar hyperplasia, and hypertrophic gastropathy. Also, increased vascular permeability due to cytomegalic vasculitis and leakage of proteins from wider tight junctions of gastric mucosa cells may lead to PLG $[3,5,7]$.

Detection of CMV in the case of PLG is sometimes difficult. CMV IgM and CMV-DNA by PCR in blood or 
gastric tissue may be helpful. In gastric biopsies, the detection of inclusion bodies and CMV-DNA by PCR is not always possible because CMV may affect the vascular endothelium or stromal cells in the connective tissue [3]. We were unable to detect CMV-DNA by PCR and inclusion bodies in biopsy specimens.

In immunocompetent children, CMV-related PLG mostly recovers under supportive treatments, such as intravenous albumin and $\mathrm{H}_{2}$ receptor blockade/proton pump inhibitors, as in our patient [3, 5-7]. Antiviral ther- apy may be necessary for healthy individuals who do not recover despite receiving supportive care for more than 2 weeks [10].

\section{Conclusion}

CMV-related PLG should be kept in mind while evaluating healthy children presenting with generalized edema without proteinuria.

\section{References}

1 Cohen JI, Corey GR. Cytomegalovirus infection in the normal host. Medicine (Baltimore). 1985 Mar;64(2):100-14.

2 Megged O, Schlesinger Y. Cytomegalovirusassociated protein-losing gastropathy in childhood. Eur J Pediatr. 2008 Nov;167(11): 1217-20.

3 Gökçe Ş, Kurugöl Z. Cytomegalovirus-Associated Menetrier Disease in Childhood. Clin Pediatr (Phila). 2017 Apr;56(4):382-4.

4 Urganci N, Gulec SG, Kilicaslan O, Basak T. Cytomegalovirus-associated protein-losing gastropathy (Menetrier's Disease) in childhood. J Acad Res Med. 2016;6(1):56-8.
5 Yoo Y, Lee Y, Lee YM, Choe YH. Co-Infection with Cytomegalovirus and Helicobacter pylori in a Child with Ménétrier's Disease. Pediatr Gastroenterol Hepatol Nutr. 2013 Jun; 16(2):123-6.

6 Blackstone MM, Mittal MK. The edematous toddler: a case of pediatric Ménétrier disease. Pediatr Emerg Care. 2008 Oct;24(10):682-4.

7 Canan O, Ozçay F, Bilezikçi B. Ménétrier’s disease and severe gastric ulcers associated with cytomegalovirus infection in an immunocompetent child: a case report. Turk J Pediatr. 2008 May-Jun;50(3):291-5.
8 Occena RO, Taylor SF, Robinson CC, Sokol RJ. Association of cytomegalovirus with Ménétrier's disease in childhood: report of two new cases with a review of literature. J Pediatr Gastroenterol Nutr. 1993 Aug;17(2):217-24.

9 Tokuhara D, Okano Y, Asou K, Tamamori A, Yamano T. Cytomegalovirus and Helicobacter pylori co-infection in a child with Ménétrier disease. Eur J Pediatr. 2007 Jan;166(1): 63-5.

10 Hoffer V, Finkelstein Y, Balter J, Feinmesser M, Garty BZ. Ganciclovir treatment in Ménétrier's disease. Acta Paediatr. 2003 Aug;92(8): 983-5. 